\title{
ROLE OF INFRASTRUCTURE DEVELOPMENT OF RURAL AND URBAN SECTOR OF INDIA
}

\author{
Krishna Somani \\ Assistant Professor, \\ Poornima University, \\ Jaipur
}

\author{
Dr. Ankita Singh Rao \\ Assistant Professor, \\ Poornima University, \\ Jaipur
}

Article DOI: https://doi.org/10.36713/epra2343

\begin{abstract}
Infrastructure is the basic requirement for development of any business or any city or country. The development of any civilization takes place when the infrastructure develops. In this paper the development in few sectors like finance, land acquisition and planning related to technologies, water, telecommunication, and energy are covered with the upcoming planning and strategies to solve the issues. If infra develops every sector of society will develop in every aspect. Government Infrastructure Projects (PPP), Government Infrastructure Projects (Traditional Procurement) and Private Sector Projects are serving in development in infrastructure.
\end{abstract}

KEY WORDS: Infrastructure, private and public investors, India, technologies, water, telecommunication, and energy.

\section{INTRODUCTION}

"Infrastructure is the term for the basic physical systems of a business or nation-transportation, communication, sewage, water, and electric systems are all examples of infrastructure". By Jim Chappelow.

The term came in late 1880 s from latin roots which means "infra" - "below" and "struere" - "to build". The fundamental or rudimentary requirements or facilities of a country or any business to undergird its economy and development. Infrastructure sector focuses on major infrastructure sectors such as power, roads and energy and urban infrastructure. This is a support system to provide secure and foundational requirements. Public sector focuses on large scale infrastructure whereas private offices or small planning seeks for small infra requirements. In 1987, a panel of the U.S. National Research Council adopted the term "public works infrastructure" to refer to functional modes including highways, airports, telecommunications, and water supplies, as well as the combined systems that these elements comprise.

\section{ROLE OF INFRASTRUCTURE IN GROWTH \& DEVELOPMENT}

Infrastructure plays a vital role in development of a country as the development of basic services provided will be respected and appreciated by local people. It is an entrepreneurial spirit. Infra investments are associated not only with public sector now, but with changing scenario it is found as partial or completely Private owned enterprise also.

Poor developed states not having proper developed road which lacked roads and highways lead to increased transportation cost and time to reach the destination, few emergencies got unsolved, and no industrialist will come to invest due to high cost resulted in low development and less growth. On the other hand, state that invested in road and connectivity development reaches heights in industrial investments and reduced transportation cost, low labour wages, reduce empowerment and good connectivity to market.

Presently, the development in infrastructure sector is at peak of booming with the support at the state and country level. The digital facilities of fastag, plastic cards and smart cards helps in smooth working of toll plazas, fast movement and hassle free and cashless payment methods. Development in connectivity like tunnels, roadways and ring road are helping in distancing and mutual tie ups in growing industrialization and trading of goods between cities and states. Energy, water and other resources reaching the rural areas and urban areas. PPP programs in which not only public sector is helping but private and 
partially private sector is also contributing equally for proper financing mechanisms, ensuring efficient project management and a wish to benefit the nation and help the humans in present and future.

Infrastructure is an asset but in India's economy and financial development it is critical to have a big portion for investment, though, the opportunities for growth and development is high and soon it will be nurturing. As funds and keen interest of private sector is noted since last few years, so the contribution of public sector along with private sector can say public and private partnerships for infra development will be fruitful.

The thirst to development infrastructure is increased as per the change in lifestyle and the quality of life one is living in urban spaces. Urbanization is holding a fast pace to come up with fruitful results in various sector. Economic Corridors or Industrial Corridors, special economic zones, riverfronts, smart city and high speed towards urbanization and many more like water supply, logistics and transportation, energy will come with a boom of Infrastructure development.

TYPES OF INFRASTRUCTURE:

\section{INFRASTRUCTURE}

\section{ECONOMY}

- Transportation- Roads, bridges, highways, ports etc.

- Energy- Power stations, national power grid; electrical power lines.

- Water- Reservoirs, dams, waterways and canals and disposal treatments.

- Technology- Telecom services,information services, networking facilities,etc.

\section{SOCIAL}

- Education- Schools, colleges, universities, liberaries ,etc.

- Health care- Hospitals, clinics, and emergency response systems.
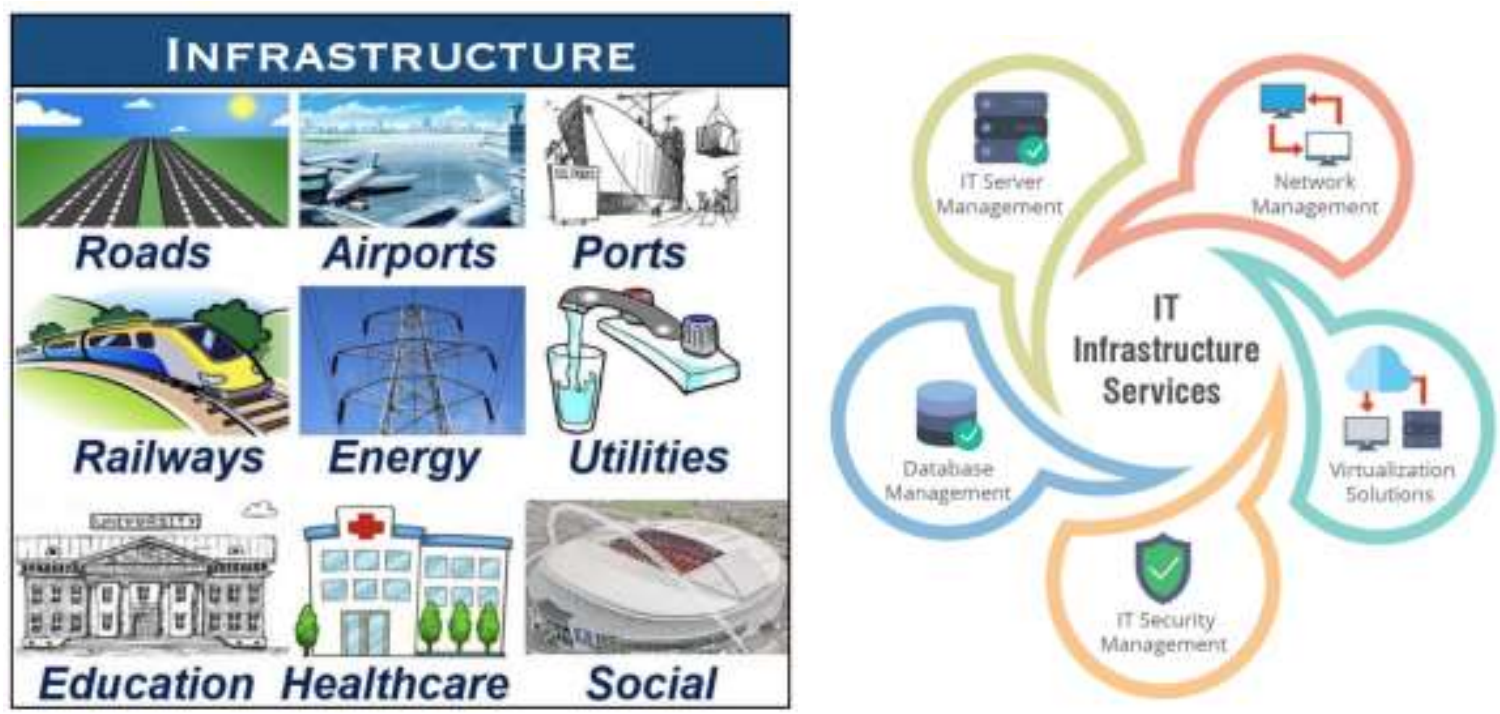

Sources of image: https://marketbusinessnews.com/financial-glossary/infrastructure-definition-means/

https://www.cloverinfotech.com/services/it-infrastructure-services.aspx 


\section{ACHIEVEMENTS OF INDIAN} INFRASTRUCTURE SECTOR:

Following are the achievements of the government in the past four years:

- Metro rail network has touched $657 \mathrm{Km}$ across india

- The largest PE investment witnessed was the Canadian asset management firm Brookfield's US\$ 1.9 billion acquisition of Pipeline Infrastructure India in first quarter of 2019.
- The total national highways length increased to $122,434 \mathrm{kms}$ in FY18 from $92,851 \mathrm{kms}$ in FY14.

- India's rank jumped to 24 in 2018 from 137 in 2014 on World Bank's Ease of doing business - "Getting Electricity" ranking.

- Energy deficit reduced to 0.7 per cent in FY18 from 4.2 per cent in FY14.

- Number of airports have increased to 102 in 2018

\section{UPCOMING INFRASTRUCTURE DEVELOPMENT:}

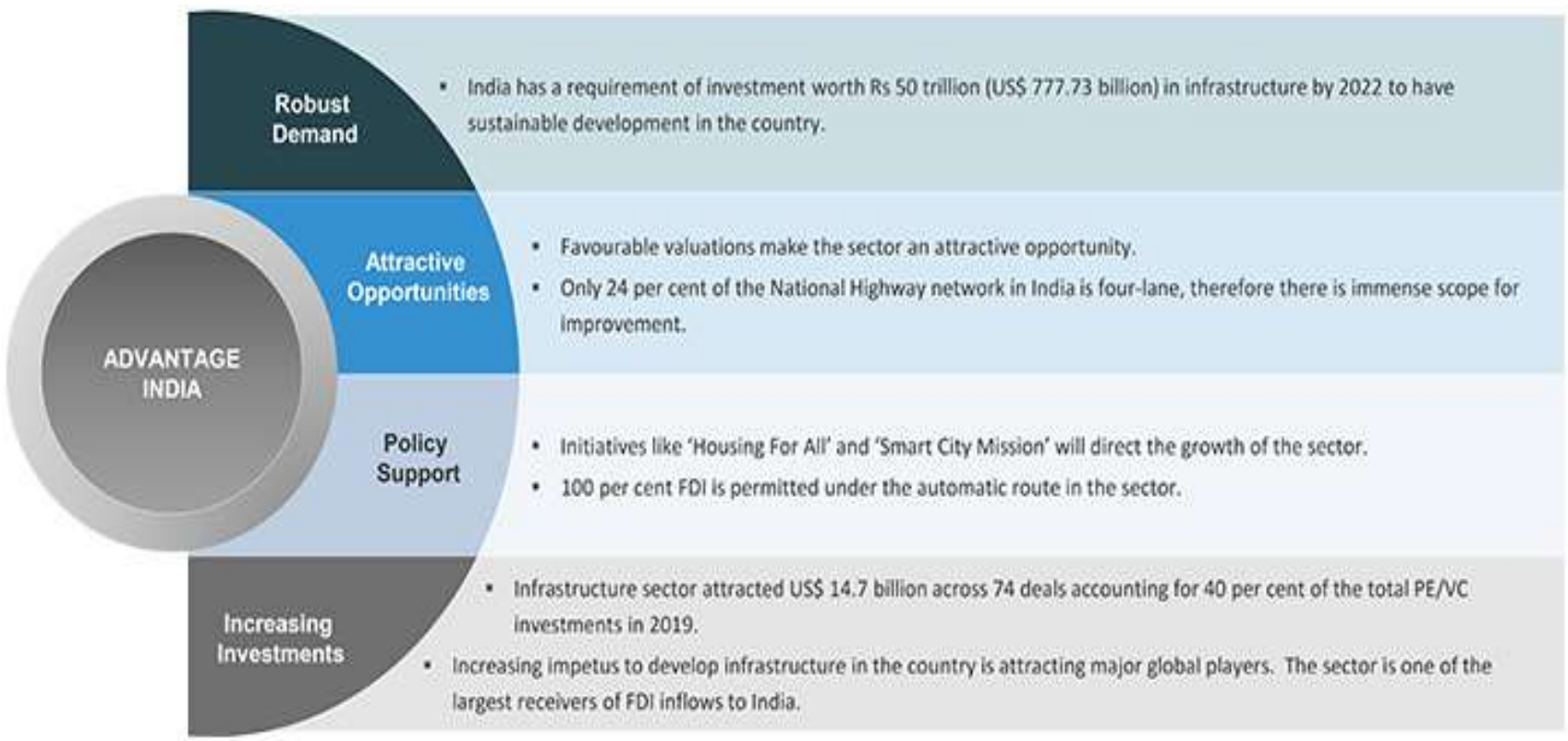

Source of images:https://www.ibef.org/industry/infrastructure-sector-india.aspx

\section{RISK FACTOR AND CHALLENGES:}

Facts of Challenges in urban infrastructure:

- Availability of drinking water supply, public transportation, sewage and solid waste management is much lower than desired.

- No city has fully covered $24 \times 7$ water supplies.

- Only $74 \%$ of the house-holds are served by piped water.
- Only 65 of 423 class I cities have a formal city bus service as of 2012 .

- Only $30 \%$ cities have sewage treatment as against desired $100 \%$.

- $7 \%$ urban population has access to the piper sewer system.

- $6 \%$ urban population lives in slums. 


\section{MAJOR ISSUES}

\section{Financial issues.}

\section{Land acquisition.}

\section{Planning oriented.}

\section{Environmental Impact Assessment(EIA).}

\section{Clearances from agencies.}

\section{SOLUTIONS TO IMPROVE INDIA'S} INFRASTRUCTURE

1. Smart freight logistics systems: Use of RFID tags or barcodes for free movement and tracking of cargos.

2. Better transportation-smart highways: Internet technologies like fastags, cameras and sensors helps in smooth working of toll plazas, fast movement and hassle free and cashless payment methods.

3. Water treatment systems: reuse of water after nanofiltration and zero liquid residue to remove harmful dissolved solids.

4. Construction methods: next generation methods in construction- use of sustainable material and strict regulatory bodies will help in timely completion of project.

5. Role of Information Technology in project handling: technological advancement on site will help in efficient Human Resource Management and eliminate errors and inefficiencies in procurements and other processes.

6. Smart cities: promote efficient use of energy, services and improve quality of life with technological development \& economic growth.

\section{REFERENCES}

1. https://www.nap.edu/read/798/chapter/1

2. Infrastructure as an Asset Class Investment Strategy, Sustainability, Project Finance and PPP by Barbara Weber, Mirjam Staub-Bisang, Hans Wilhelm Alfen

3. https://www.investopedia.com/terms/i/infrastruct ure.asp

4. https://www.ibef.org/industry/infrastructuresector-india.aspx

5. https://www.india.gov.in/topics/infrastructure

6. https://www.infrabazaar.com/blog/Challenges-ofInfrastructure-Industry-in-India/283

7. https://marketbusinessnews.com/financialglossary/infrastructure-definition-means/
8. https://www.cloverinfotech.com/services/itinfrastructure-services.aspx

9. https://www.gktoday.in/gk/issues-and-challengesto-urban-infrastructure-in-indial 